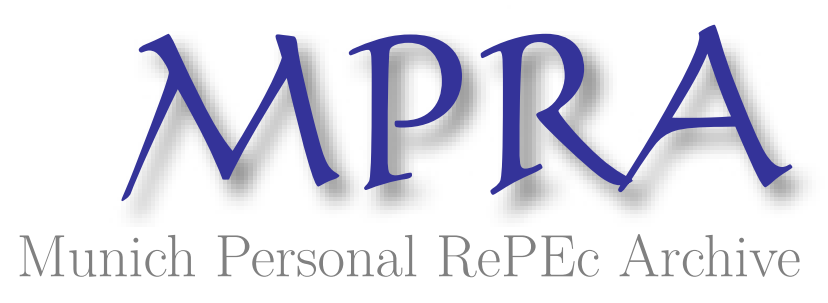

\title{
The Historical Origins of Poverty in Developing Countries
}

Bhattacharyya, Sambit

April 2016

Online at https://mpra.ub.uni-muenchen.de/67902/

MPRA Paper No. 67902, posted 16 Nov 2015 18:31 UTC 


\title{
The Historical Origins of Poverty in Developing Countries
}

\section{Sambit Bhattacharyya}

\section{University of Sussex}

26 September, 2012

Forthcoming in D. Brady and L. Burton (eds.) Oxford Handbook of Poverty and Society, Oxford University Press.

\begin{abstract}
In this chapter I explore the causal relationships between historical factors (for eg., geography, disease, colonial history, and technology) and poverty in developing countries. I start with a review of the existing theories. This is followed by a novel unified framework in order to causally relate these historical factors in explaining the process of development in Western Europe and the New World colonies. The final section applies this framework to explain why Africa, Latin America, and Russia fell behind. My central argument is that Western Europe benefitted from favourable geography which led to highly productive agriculture, food surplus, and institutions conducive to development. In contrast, Africa continues to suffer from unfavourable geography and disease. Institutional weaknesses in Latin America and Russia explain their relatively weak long term economic performance. I also argue that these historical factors matter for contemporary patterns of development across the globe. The chapter concludes with some suggestions for future research on this topic.
\end{abstract}




\section{Introduction}

The recent economic growth record of the developing world has been the subject of many discussions. Indeed, some nations in the developing world have been growing at an enviably rapid pace. In spite of such dynamism in some developing economies, the gap between the rich and the poor nations of the world is wider than ever. According to a latest estimate, 1.4 billion people are trapped in extreme poverty and reside in developing countries (IFAD, 2011). At the macro level, the latest World Bank estimates suggest that the divide between rich and poor nations is even more striking. Norway, the world's richest nation with per capita income $\$ 84,290$ is 496 times richer than Burundi, the world's poorest country with per capita income $\$ 170$.

In this chapter I explore the genesis of this divergence. During the second half of the previous century, the vast majority of the intellectual efforts by economists and social scientists in the quest for growth were focused on exploring the post second world war period. However, simple plots of GDP per capita across nations show that there is very little change in the relative positions of countries since the war (see Figure 1). The difference in living standards in India and the United Kingdom hardly changed since the war. The gap between Ghana or Tanzania and the industrial West widened during this period. The only exception however is China as the Chinese economy showed immense dynamism since the 1970s and is rapidly catching up with the industrial West. ${ }^{1}$ In spite of such dynamism, the gap between China and the industrial West still remains significant. Therefore, the genesis of this gap cannot be the post war period. To trace the origin of divergence, we need to look further back in time.

In order to systematically analyse the root causes of poverty in developing countries, I start with a review of the theories of root causes (geography, disease, colonial history, slave

\footnotetext{
${ }^{1}$ Another recent success story is South Korea. See Milanovic (2005).
} 
trade, culture, and technology) of poverty. Following which, I present a novel unified framework which unites these theories. The central thesis is that Western Europe benefitted from favourable geography which led to highly productive agriculture, food surplus, and institutions conducive to development. In contrast, Africa continues to suffer from unfavourable geography and disease. Institutional weaknesses in Latin America and Russia explain their relatively weak long term economic performance. I also argue that these historical factors matter for contemporary patterns of development across the globe.

The main contribution of the chapter is to present a novel unified framework. The framework links root causes such as geography, disease, colonial institutions and technology in order to describe the history of long term development in Western Europe and North America. It is also used to judge what went wrong in Africa, Latin America and Russia.

The chapter is organized as follows. In section 2, I start with a critical analysis of the existing theories of root causes. Section 3 presents a unified framework for Western Europe relating factors such as geography, disease, colonial history, and knowledge in explaining economic progress. Section 4 applies this framework to explain the history of poverty in Africa, Latin America, and Russia. Section 5 concludes the chapter.

\section{Theories of Root Causes of Poverty}

\section{Institutions and Development}

Economists, philosophers, and other social scientists have been grappling with the role of institutions in delivering prosperity at least since the days of European and Scottish enlightenment. The role of institutions in reducing poverty and promoting development has been articulated well in his elegant prose by Adam Smith. Smith (1776), in his seminal book The Wealth of Nations writes, "Little else is required to carry a state to the highest degree of opulence from the lowest barbarism, but peace, easy taxes and tolerable administration of justice; all the rest being brought about by the natural course of things". 
Even though many scholars since Adam Smith have referred to the role of institutions, it is perhaps due to the works of Nobel laureate Douglass North in the 1980s the institutions and development theory returned back to the centre stage of mainstream economics. North (1994) defines institutions as humanly devised constraints that structure human interaction. He also classifies these constraints into formal and informal and shows that they depend on the enforcement characteristic. The constraints and the enforcement characteristics taken together form the incentive structure of a society and are crucial to innovation, investments, poverty reduction and prosperity.

The institutions and development theme has also been advanced by Evans (1995) and Amsden (2001). Evans (1995) distinguishes between developmental and predatory states in developing nations and analyse their impact on economic development. Amsden (2001) on the other hand highlight the importance of flexible institutions which allows for ingenious and more independent industrial policy in developing countries.

Following Douglass North's and others work on economic institutions many of the recent empirical studies test the statistical significance of the institution variables in explaining the variation in living standard across countries. Knack and Keefer (1995) and Hall and Jones (1999) are perhaps the early studies to use institutions and governance as explanators of the variation in poverty and prosperity across nations. They use measures of institutions as explanatory variables in a regression model with GDP per capita as a dependent variable and show that they are statistically significant.

Even though many of the early empirical studies report statistical significance, questions were raised about the direction of causality in the relationship between institutions and economic performance. One could argue that causality runs from institutional quality to economic performance. However, one could also argue that richer nations are better able to afford good institutions and therefore causality runs from GDP per capita to institutional 
quality. Acemoglu et al. (2001) is perhaps the first to put forward an empirically validated causal explanation in this literature. They assert that the Europeans resorted to different style of colonisation depending on the feasibility of settlement. In a tropical environment the settlers had to deal with malaria and yellow fever and they faced a high mortality rate. This prevented them from settling in a tropical environment and resource extraction became the most important if not the only activity in these colonies. In order to support these activities, the colonisers erected institutions which were extractive in nature. On the other hand, in temperate conditions European settlers felt more at home and decided to settle. In these places they erected institutions characterised by strong protection of property rights and efficient enforcement of contracts. These institutions persisted over time and influenced the incentive structure in these societies. Therefore, the shaping of the incentive structure during the colonial period has a long-run impact on economic development which is reflected by the current standard of living of these places.

Using data on European settler and clergy mortality rates from the colonies Acemoglu et al. (2001) show that indeed there is a negative correlation between settler mortality and current institutional quality. Furthermore, they also show that institutional quality has a positive impact on the current level of development. This leads them to conclude colonial institutions systematically influence the living standards of citizens in the former European colonies.

In another paper published the following year Acemoglu et al. (2002) show that the economic fortunes of the former European colonies reversed after colonization. Colonies that were prosperous prior to European colonization became poorer whereas economically backward colonies became prosperous after colonization. They attribute this 'reversal of fortune' to institutional reversal. They argue that economically effective institutions of previously prosperous tropical colonies were replaced by extractive institutions after 
colonization. These institutions persisted over time and are not conducive to capitalism. In contrast, in settler colonies strong property rights and contracting institutions were set up which were conducive to capitalism. They also argue that the 'reversal of fortune' is strong evidence in favour of the dominance of the institutions view and it nullifies the role of factors such as geography. Note that the influence of geography remained unchanged both before and after colonial intervention. The institutions however experienced a reversal after colonization.

The 'reversal of fortune' argument was not limited to the economics literature. Lange et al. (2006) argue that the 'reversal of fortune' was more to do with the style of colonialism than colonialism per se. They argue that Mercantilist Spain extensively colonized regions that were more prosperous and populous. Mercantilist and extractive policies of Spanish colonialism was extremely harmful for these colonies. In contrast, liberal British colonialism targeted areas that were sparsely populated and less developed. They set up institutions that were liberal and conducive to capitalism. Therefore, these colonies experienced rapid development under British colonialism.

Note that Lange et al. (2006) is not unique in comparing British and Spanish colonial institutions. North (1989) and La Porta et al. (1999) also presents a similar argument. North (1989) contrasts the evolution of British Common Law and its influence on colonies such as the United States with the centralized institutional enforcement mechanism of Spain and influence on South American colonies. La Porta et al. (1999) in contrast focuses on the influence of British and Spanish legal origins.

A series of empirical papers followed after these two influential papers. Rodrik et al. (2004) test the institutions hypothesis against statistical proxies of the geography and trade hypotheses respectively. They find that institutions are the only dominant factor explaining the difference in living standards across countries. Bhattacharyya (2009b) estimates the 
impact of different types of institutions on growth. He shows that 'market creating institutions' such as property rights and contracts are the key for prosperity. Regulatory institutions matter only up to a certain extent whereas political institutions such as democracy do not seem to matter. In a similar vein Acemoglu and Johnson (2005) test the relative importance of property rights and contracting institutions and find that the former is relatively more important than the latter.

Independently, Engerman and Sokoloff (2001) focus on the roles of initial endowment and distribution of political power in shaping institutions. Comparing North and South America they write, "While all [New World colonies] began with an abundance of land and other resources relative to labour, at least after the initial depopulation, other aspects of their factor endowments varied - contributing to extreme differences in the distributions of land holdings, wealth, and of political power."

They argue that the climatic conditions of North American colonies were favourable to growing grains and keeping livestock. The production technology involved with these agricultural activities exhibited limited economies of scale in production. Therefore, small family sized farms were preferred over large landholdings. This led to a more equitable distribution of land and wealth. This had a profound impact on the initial distribution of political power and political institutions. These political institutions honoured the right of citizens to own private property and hence protected them. They also enforced contracts. The property rights and contracting institutions taken together were key ingredients for the creation of a thriving local market economy. The local market economy were also well connected with the European economies at the other side of the Atlantic and delivered shared prosperity. This in turn created a culture of more equitable distribution of political power which helped these institutions to persist and thrive. The idea of a property owning democracy with universal male suffrage was unprecedented in the political history of the 
world. The success of these institutions in the North later led to the adoption of these institutions in Western Europe.

In contrast, climatic conditions in South America and the Caribbean islands were conducive to cash crops such as sugar, tobacco, rubber, and cotton. This continent was also home to a vast amount of mineral resources. Production technology involved in the plantation of cash crops and extraction of mineral resources can benefit from large economies of scale. Therefore large plantations and mines were set up in these regions. These plantations and mines were owned by a minority group of European colonizers whereas they were run by large armies of cheap slave labour. The working population in these colonies was extremely poor and had no political rights or power. Any revolt by the enslaved workers was often brutally quashed by the colonial masters. This led to an unequal initial distribution of wealth and political power in these colonies. The highly concentrated landholdings and extreme inequality in Mexico, Colombia, and Peru during the colonial period are supportive of Engerman and Sokoloff's (2001) theory on the Americas. This skewed distribution of wealth and political power contributed to the development of political and economic institutions that were exploitative and extractive in nature. These institutions persisted over time and continue to inhibit the development of markets, an advanced capitalist economy, and conditions for sustained economic growth in the South.

The debate on institutions and development in political science is somewhat dominated by sociologist Seymor Martin Lipset's (1959) 'modernisation hypothesis' which says that as countries develop, their quality of institutions, education, and health service improves simultaneously. In other words, the causality runs from living standards to institutions and not the other way around. However, this view has been challenged by recent research. A potent counterargument is that institutions diverge not in a systematic manner as outlined by Lipset (1959), but due to exogenous shocks at critical historical junctures. 
Barrington Moore (1966) in his famous work on institutions outlines that events such as the Russian Revolution, the American Civil War and many others are critical junctures in history which shapes future institutions and economic trajectory. This is commonly known as the 'critical juncture hypotheses'. Thelen (1999) and Thelen (2000) also make a case for the 'critical juncture theses' in explaining German labour history and institutions. Thelen (1999) also presents a survey of the 'critical juncture' literature in politics.

Another strand of the institutions literature is inspired by the works of Giovanni Arrighi, Terence Hopkins and Immanuel Wallerstein. Arrighi et al. (1989) in their book entitled 'Anti-systemic Movements' argue that anti-systemic movements or revolutions arising out of class struggle in a capitalist society could be transient as the institutions of class characterized by old Marxists are in a constant state of flux. They argue that in a capitalist world-economy due to the rapid change in technology and the mode of production groups and institutions are constantly recreated, remoulded and eliminated.

\section{Institutions of Slave Trade and Development in Africa}

A large literature also links the institutions of slave trade and poverty trap in Africa. The major contributors are Inikori (1977, 1992), Manning (1981, 1982), and Miller (1988).

Inikori (1992) argues that a vast majority of slaves that were exported were free individuals captured by force. The capture took a number of forms notably kidnapping, raids organised by the state, warfare, pawning, via the judicial procedures, tributes etc. Firearms were imported from the Europeans in exchange for slaves particularly during the period 1750 to 1807 which were used for capturing more slaves (Inikori 1977). Inikori (1992) also shows that the rise of Atlantic salve trade led to more capturing and the expansion of the African salve trade. The increase in the trade for captives institutionalised banditry and corruption for more than three hundred years in the continent weakening institutions which retarded socioeconomic development (Inikori, 2000). 
Manning's argument is also similar to Inikori however his work focuses on Dahomey which is roughly the area around the Bight of Benin during the period 1640 to 1860 (Manning 1981, 1982). He observes that the immense increase in slave prices with a price elasticity of supply of 1.5 created the incentive for capturing more slaves. Institutions (which included warfare, raiding, kidnapping, judicial procedures, and tributes) were set up during 1640 to 1670 in this area which was conducive to capturing slaves. The state became an active participant in the collection and delivery of slaves which is further evidence favouring Inikori’s argument. Miller (1988) also provides a similar account in case of Angola.

More recently, Nunn (2008) using regression models show that slave trade prevented state development, encouraged ethnic fractionalisation, and weakened legal institutions. Through these channels, slave trade continues to affect current economic development in Africa. However, Bhattacharyya (2009c) shows that Nunn's empirical evidence is not robust to the inclusion of malaria and other geography variables.

\section{Geography and Development}

Jared Diamond's influential book entitled 'Guns, Germs and Steel' is perhaps the most comprehensive account of the role of geography in economic development in recent times.

Diamond (1997) in his book asks the question: why did history unfold so differently on different continents? He argues that geography and biogeography influenced humanity in contrasting ways in different continents. Geographical conditions and climate in different continents created different endowments for food and livestock. In the Eurasian plain especially in south west Asia by the Mediterranean, the climate was best suited for the development of a large number of edible wild grains and large mammals. Diamond (1997) follows University of Chicago archeologist James Henry Breasted ${ }^{2}$ and calls this region the

\footnotetext{
${ }^{2}$ James Henry Breasted was the first to use the term 'Fertile Crescent' in his book Ancient Records of
} Egypt published in 1906. 
'Fertile Crescent' ${ }^{3}$. Early hunter-gatherers domesticated a large number of these edible wild grains and resorted to a sedentary agriculture based lifestyle. ${ }^{4}$ They also domesticated a large number of large mammals and used them for their milk, meat and muscle power. Milk and meat from domesticated animals became a reliable source of protein which increased productivity of agricultural labour. Usage of muscle power of large domesticated animals in agriculture also boosted agricultural productivity and contributed to food surplus. This farming technology, knowledge, domesticated crops and animals, and surplus food traveled along the same latitude to other parts of the Eurasian plane. These animals and crops thrived in the geographic conditions of Western Europe. Western Europe has glaciated extremely fertile soil, reliable rainfall, and very few debilitating tropical diseases. These conditions were ideally suited for further development of these crops and domesticated animals. Agricultural productivity improved even further which consistently contributed to food surplus. A reasonably long history of sedentary agriculture along with animal domestication led to frequent outbreaks of epidemic diseases. This helped the Eurasian population develop vital immunity against many epidemic diseases. Powered with immunity and food surplus these societies experienced population growth. Societal structure became more complex and sedentary lifestyle led to the development of guns, steel swords, sea worthy vessels etc. When the non-Europeans in the Americas and Africa came into contact with the Europeans during colonial conquest, the former were able to offer very little resistance to the latter as the latter were powered with guns, steel swords, horses, ocean navigable ships, and germs. Many of the Native American population perished from alien Eurasian diseases such as small pox. As a

\footnotetext{
${ }^{3}$ The Fertile Crescent spans a part of the modern day Israel, Palestine, and Jordan valley. For further reference see map in Diamond (1997) p. 135.

${ }^{4}$ Note that even though most human societies experienced a transition from being hunter-gatherers to sedentary agriculture based societies, there are quite a few exceptions to this rule. See Diamond (2012) for a list.
} 
result, over time the Europeans became more and more prosperous relative to the rest of the world.

Diamond's thesis of the origin of productive agriculture in the 'Fertile Crescent' is also supported by archeobotanists Daniel Zohary and Maria Hopf. Zohary and Hopf (2000) in their book Domestication of Plants in the Old World presents evidence that the extensive spread of wild barley was confined to the 'Fertile Crescent'. They also show that the wild ancestors of modern wheat (the emmer wheat and the einkorn wheat) and wild ancestors of other 'Fertile Crescent' crops originated in the 'Fertile Crescent'.

Similar to Diamond's theory on the role of geography, Olsson and Hibbs (2000) and Gallup and Sachs (2000) emphasize the role of agriculture in explaining current levels of development. Olsson and Hibbs (2000) show that on average nations with long history of agriculture tend to be richer than nations with relatively short history of agriculture. Highly productive and organized agriculture began in Europe approximately 9000 years ago. In contrast agriculture in equatorial and subequatorial Africa started approximately 2000 to 1800 years ago. The length of agricultural history is also correlated with the development of the state. Europe acquired some early form of government much earlier than Africa. Therefore, it is not surprising that contemporary Europe is far more economically advanced than contemporary Africa. Gallup and Sachs (2000) however focus on the influence of soil quality on agricultural productivity and economic development. They argue that high relative humidity and high night time temperature in the tropics cause high plant respiration and slows down plant growth. This deficiency in plant growth in the tropics is also related to the lack of nutrients in tropical soil. Humid tropical soils (alfisols, oxisols and ultisols) are typically low in nutrients and organic matters. This limits plant growth and also causes soil erosion and acidification. In addition the lack of frost allows a greater number of pests to survive and breed. These factors have a debilitating impact on agricultural productivity and 
inhibit economic progress. In contrast European and temperate regions are blessed with extremely fertile glaciated soil and more frost days to eliminate pests. Therefore, agricultural productivity is much higher.

Geography can also impose severe constraints on trade and commerce (Sachs and Warner, 1995; Sachs and Warner, 1997; and Gallup et al., 1998). Many countries are landlocked and as a result have no or limited access to ports and ocean navigable waterways which limits their ability to trade. Access to a port or major markets in such situations often involve crossing international borders which makes the cost of transportation relatively high. Limited international trade in these economies confines all commercial activities into small internal markets. This causes an inefficient division of labour and underdevelopment. Inland Africa and some Central Asian countries are perhaps good examples of the perils of unfavourable geography (Collier and Gunning, 1999).

Even though Jared Diamond's influential book brought back the role of geography and climate to the centre stage, by no means Diamond's work is the first. The climate and geography argument could be traced as far back as Montesquieu (1748). He argues that the population in the tropics is not industrious enough largely due to the energy sapping heat. Natural availability of food in abundance also makes tropical people idle. This has a direct and negative effect on human productivity and hence economic growth. In a recent study, Parker (2000) supports Montesquieu's argument. According to his thesis, an individual's desire to maximize utility is dependent on motivation, homeostasis and neural, autonomic, and hormonal adjustments. These physiological factors are governed by the hypothalamus. The activity of the hypothalamus is heavily dependent on thermodynamics. In hot conditions, the hypothalamus secretes hormones which negatively affect motivation and enterprise; whereas in the cold climate individuals are naturally hard working. These tendencies affect the steady state level of income in these two regions. The average steady state income in the 
cold climate is naturally higher than the average steady state in the hot climate. Hence, climate explains two thirds of the per capita income differences between the tropics and the temperate.

\section{Disease and Development}

Demographers have long talked about the role of mortality and fertility in transforming a society. The idea of how mortality and fertility shapes a society at least goes back to Malthus. When societies are faced with high birth rates without a significant increase in food production, then it is likely that the mortality rate would rise. In contrast, an increase in food production would be followed by a significant increase in the birth rate as the society is better able to support a larger population. In recent times a more sophisticated version of this theory has evolved which is commonly known as the 'theory of demographic transition'. The demographic transition theory suggests that as societies become more economically advanced then they focus more and more on the quality of newborn rather than their quantity. The survival rate of newborns in an economically advanced society improves alongside life expectancy. As a result households concentrate more on quality rather than quantity and both fertility and mortality declines. The transition from an economically backward high fertility and high mortality equilibrium to an economically advanced low fertility and low mortality equilibrium is commonly known as the demographic transition.

Disease influences both mortality and fertility and therefore delays demographic transition. Therefore in an environment of high disease incidence a society could be trapped into a low level equilibrium often referred to as the poverty trap. Bhattacharyya (2011) presents a model to outline the mechanism through which disease could impact on development. High disease incidence increases mortality and therefore affects individual's savings and investment decisions. If the probability of survival into the future is low then individuals are more likely to focus more or current consumption and save less for the future. 
As a result of low savings, investments in the future would suffer. Furthermore, morbidity could also be high in an environment where debilitating diseases such as malaria are prevalent. Therefore, low labour productivity would also be an issue. These factors taken together would lead to a poverty trap (Gallup et al., 1998).

The link between disease and economic development is empirically established by Gallup and Sachs (2001), Bloom and Sachs (1998) and Gallup et al. (1998). Gallup and Sachs (2001) point out that the countries with intensive malaria grow 1.3 percentage points slower per person per year than countries without malaria and a 10 percentage point reduction in malaria might result in a 0.3 percentage point increase in annual per capita income growth. Bloom and Sachs (1998) also claim that the high incidence of malaria in sub-Saharan Africa reduces the annual growth rate by 1.3 percentage point a year. In other words, eradication of malaria in 1950 would have resulted in a doubling of current per capita income. Sachs (2003) reports a strong and negative effect of malaria on economic progress even after controlling for institutions and openness.

More recently Bhattacharyya (2009c) show that the fundamental cause of lack of development in Africa is malaria. Using an empirical model and the instrumental variable method of estimation to estimate the long run impact of malaria, slave trade, and institutions on living standards in Africa he finds that malaria is the only statistically significant explanatory variable. Factor such as slave trade and institutions are statistically insignificant. The purported link between slave trade and current living standards through institutional quality also breaks down in the presence of malaria. Bhattacharyya's findings are also a confirmation of a long list of earlier research findings in the field of tropical medicine that malaria in Africa is different from the rest of the world (Kiszewski et al., 2004). Malaria in Africa is vector ${ }^{5}$ based and tropical countries are saddled with diseases that present a much

\footnotetext{
${ }^{5}$ In epidemiology literature, a vector is defined as an agent (person, animal or microorganism) that
} 
bigger challenge for the local population relative to temperate countries. These diseases are a product of tropical biology and it is somewhat misplaced to brush off the disease argument by claiming it to be endogenous to institutional and state capacity. In other words, financially well-resourced states could easily overpower malaria. Hence it is not the severity of the disease but institutional weakness which is the root cause of African underdevelopment. It is important to note here that in spite of the billions pumped into research in tropical medicine to eradicate these diseases over the last and the current century, it is still proving to be illusive. Strategies such as vector control also turned out to be unsuccessful. Therefore, the endogeneity argument often bandied about in the economics literature seems somewhat illinformed. Kiszewski et al. (2004) presents an excellent summary of the research in tropical medicine.

\section{Technology and Development}

The technology and human capital theory of development was formalized in economics by Joseph A. Schumpeter (1934). In his book entitled The Theory of Economic Development he describes the notion of 'creative destruction' and how it is central to the process of economic development. He argues that every enterprise in a capitalist economy is constantly searching for new ideas to outsmart their competitors. A commercially viable new idea comes with the privilege of enjoying monopoly profit in a particular product range. Therefore, product differentiation is the key to success and constant innovation is the main driver of product differentiation. The process of creative destruction and product differentiation could render previous products obsolete and capture their market. This round the clock dynamism of the capitalist economy creates incentive for entrepreneurs to invest in $R \& D$ in their quest for a larger market share. Schumpeter argues that this is what creates value and keeps capitalism marching forward.

carries and transmits an infectious pathogen into another living organism. 
Historian Joel Mokyr in his influential book The Lever of Riches also credits new technology for the success of capitalism. He identifies technological progress as the lifeblood of economic progress in all human societies. He writes, "Technological progress predated capitalism and credit by many centuries, and may well outlive capitalism by at least as long" (Mokyr, 1990; p. 6). He however puts more emphasis on the complementary role played by invention and innovation in the success of a society. Using anecdotal evidence from European and Chinese history he shows that both invention and innovation should go hand in hand for the success of a society. Even though in the short run one could make up for the other, in the long run one could not survive independently and without the other.

Supporting the technology and human capital view of development Glaeser et al. (2004) focuses on the causes of success of some of the former European colonies. They argue that when the European settlers migrated to the New World, they took their knowledge and human capital with them and not institutions. The Anglo-Saxon colonies of the north received migrants predominantly from industrial Britain and Western Europe. Consequently their migrant stock had relatively high levels of knowledge and human capital. In contrast, the Spanish and Portuguese colonies of the south received migrants predominantly from the not so industrial European south. Consequently their migrant stock had relatively low levels of knowledge and human capital. These differences in knowledge and human capital persisted and continue to explain the difference in living standards in these former colonies. Therefore, human capital could be more fundamental than institutions behind the success of the northern New World colonies. Even though their argument seems feasible, Bhattacharyya (2009b) show that statistically it is difficult to identify these effects.

Another strong case for the human capital and development view is put forward by Galor and Moav (2006). They argue that after the industrial revolution in Britain the factory system became the dominant model of production. The three major factors used in the factory 
system of production were land, labour and capital. However, land became secondary relative to the other two factors over time. The owner of labour was the workers and the owner of capital and land were the capitalists. The society also became segmented along the lines of ownership of factors and this gave rise to a class society. The owners of labour were part of the working class and the owners of capital and land were part of the capitalist class. However, over time the class society broke down. Galor and Moav associate this demise of the class society to technological progress. At the start of the industrial revolution production technology was fairly basic and therefore the demand for skilled labour was low. However, the demand for labour shifted more towards skilled labour as production and machineries became more complex towards the latter part of industrial revolution. In order to maintain their profit levels, capitalists started investing in schooling to create a steady supply of skilled workforce. This is in sharp contrast to the early part of industrial revolution when the usage of child labour in factories was rife. ${ }^{6}$ During the latter part of industrial revolution Britain experienced the rise of the Victorian do-gooders - a group of entrepreneurs actively engaging in philanthropy to improve public welfare through building schools, hospitals, and proper sanitation. Therefore, technology not only helped economic progress of the society but it also brought about changes in political and social institutions.

Galor and Moav (2006) also provide empirical evidence in favour of their theory using the voting patterns of the legislators on England's education reform, the Balfour Act of 1902. This bill was meant to create a publicly supported secondary school system. They show that legislators' support for this bill is positively correlated with the industrial skill-intensity level of the counties. Legislators representing counties with high industrial skill-intensity level overwhelmingly supported this bill whereas the others didn't. By assuming that the legislators received financial backing from the industrialists of their respective counties, they

${ }^{6}$ Dickensian stories of the Oliver Twists of early industrial England are a chilling testament of industrial practice during that time. 
argue that this result reflects the eagerness of the capitalists owning skill intensive industries to invest in human capital.

\section{Culture and Development}

Max Weber's seminal work entitled 'The Protestant Ethic and the Spirit of Capitalism' is perhaps one of the earliest scholarships highlighting the importance of religion and culture. Weber (1930) argues that Protestantism's and especially Calvinism's emphasis on industry, thrift and frugality along with its moral approval of risk taking and financial selfdevelopment created a social environment conducive to investment and the accumulation of private capital. These values sowed the seeds of modern capitalism. Weber's views are rejected by Tawney (1926) who argues that it was secularism and not Protestantism which bolstered the forward march of industrial England in the sixteenth century.

Other noteworthy theories of culture are due to Landes (1998) and Clark (2007). Landes (1998) argue that religious tolerance of Protestantism is one of the key virtues which facilitated capitalism. Clark (2007) on the other hand emphasizes the role of religion and middle class virtues of thrift and hard work. In spite of their intellectual appeal, the supporting evidence provided by these authors is often found to be unreliable (Allen, 2008).

\section{Unified Framework}

In the previous section we observed that multiple factors may have influenced the process of economic development or the lack of it. Therefore, it is unlikely that a process as complex as economic development may have been driven by one single factor. In this section I present a novel unified framework similar to Bhattacharyya $(2009 a, 2011)$ to show that it was not one factor but a series of factors which created the difference between success and failure throughout human history. ${ }^{7}$ The idea here is to construct a framework to explain the Western European and later North American success story. The unified framework emphasizes the

\footnotetext{
${ }^{7}$ Note that these sections draw on a variety of historical accounts notably, Diamond (1997), Engerman and Sokoloff (2001) and Acemoglu et al. (2005).
} 
important roles of geography, disease, trade, and institutions in the development of Western Europe and North America. In the next section I will compare this framework with African, Latin American, and Russian historical narratives to identify why they fell behind. I discuss the roles of the abovementioned factors in turn. Table 1 also provides a summary of factors that may have influenced development across the globe.

\section{Western Europe}

Western Europe benefitted from the transfer of seeds and agricultural technology from the East. Organized and productive agriculture started in the 'Fertile Crescent' approximately 11,000 years ago (Diamond, 1997). Local population domesticated wild varieties of modern wheat and barley which were plentiful in the 'Fertile Crescent'. They also domesticated large mammals which were a reliable source of protein. These crops migrated westwards to Europe along with humans. As a result organized agriculture started in Europe around 9000 years ago. Agriculture, food surplus and sedentary lifestyle increased human population in Europe. Increased population created more pressure on cultivable land which led to frequent armed conflicts between villages and tribes. Armed conflicts and warfare necessitated the creation of a more complex and hierarchical institutions within the society. Armed conflicts also led to technological progress especially in metallurgy which had a direct positive externality on agriculture. Agricultural productivity improved further and human society became more complex relative to the initial hunter-gatherers.

In spite of such progress, humans in Western Europe were not as advanced as modern industrial societies. Due to intensive agriculture and increased population density humans were living side by side to domesticated animals and other humans. This led to more frequent outbreaks of deadly and infectious diseases such as cholera, bubonic plague, and small pox. Even though these frequent outbreaks took a heavy toll on the human population in Western 
Europe, it also boosted immunity. Furthermore, it also necessitated the development of the art of alchemy and early medicine to treat diseases.

In the middle ages, investments in science and technology coupled with increased immunity boosted human population even further. Growing demand for food necessitated intensive agriculture and exploiting increasing returns to scale in agricultural production. Farm size became larger and larger. New farming tools coupled with new farming techniques increased agricultural productivity even further. Protection of food surplus and agricultural land from frequent armed invasions by other villages and tribes necessitated the creation of full time military force. A complex reorganization of society took place at this point. Leaders of military force started getting more and more prominence within the society. In return for their military service the leaders established the right to expropriate a part of the agricultural produce. This is what modern societies would call taxation. With taxation came the need for accounting and documenting who is paying what and when. As a result institutions became more formalized.

Towards the later part of the middle ages as population density increased, so increased the greed of the European feudal elites to bolster their coffers by waging wars and acquiring new territory. During this period Western Europe experienced virtually unabated armed conflicts. The increasing predominance of the military within a society gave rise to a new kind of social organization. Feudal elites forged coalition often along ethnic lines and increasingly appeared to be united as an imperial nation state under the monarch.

Frequent conflicts and the culture of waging wars weakened the coffers of the Western European monarchs. They started looking elsewhere for more riches to plunder. The Spanish and the Portuguese monarchs commissioned exploratory voyages intended to discover direct trading routes to the East and eliminate the Arab middleman. They were also inspired by the tales of great riches (especially precious metals such as gold) of the East. 
Their quest for precious metals were satisfied, albeit accidentally, not from the East but by reaching the shores of South America. Francesco Pizzaro's ransom in terms of gold to free Atahualpa after the battle of Cajamarca is perhaps a testament to the Western European imperial glut for precious metals.

The opening up of the trade routes across the Atlantic led to large scale exploitation of gold and silver mines in South America. This steady flow of metals into Europe (especially Portugal and Spain) led to inflation and the monarchs by default adopted mercantilist policies (Bhattacharyya, 2011). Monarchs wanted to prevent precious metals from going out of the country so they restricted import of manufactured goods. The focus shifted from import of manufactured goods from India and China to the export of manufactured goods.

Increasingly from the seventeenth century onwards Western European monarchs engage in naval conflicts with each other for control over trade routes. First it was the Portuguese, then the Spanish, followed by the Dutch, French and English established trade companies to wrest control of the trade routes. Finally the English prevailed over the rest and established themselves as the supreme naval and military power of Europe. The English imperial fortunes were bolstered by acquiring new land to expand the empire, increased tax revenue, and sometimes outright plunder.

The English merchants and monarchs developed a symbiotic relationship over this period. Merchants trading in the high seas required the support of the military and the monarch. The monarch in return also required the support of the merchants for credit, tax revenue, and a share of the plunder from the colonies. This symbiotic relationship galvanized through the development of new economic and political institutions. The merchants demanded more political rights and protection from expropriation by the monarchs and the elites. Their newfound economic power enabled them to impose more 'checks and balances' on the monarch, protect property rights, establish parliament, and seek more political power. 
These institutions were pivotal to the success of capitalism and the industrial revolution. Unfettered and sometimes favorable access to overseas markets in other parts of the empire without doubt helped the cause of industrial revolution.

Britain's involvement in the triangular trade of the Atlantic economy may have helped the industrial revolution (Findlay, 1990) even though conclusive evidence on this remains elusive. Cotton textile, sugar, rum, and guns produced in Manchester, Liverpool and other parts of industrial England were traded for slaves in Africa till the abolition ${ }^{8}$. Merchants and slave traders would exchange these goods with African warlords and slave raiders in return for slaves. These slaves would be exported to the Caribbean and the American South to work in sugar and cotton plantations respectively. Raw sugar and cotton from the new world would then be exported back to England for processing in the industrial mills.

The capitalist economic institutions survived and bolstered by more representative political institutions. These economic and political institutions were key to the success of capitalism in England. These institutions and the ideas of industrial revolution also spread to the continental European west and contributed to the success of capitalism there.

In summary, the success of Western Europe is due to multiple factors. To start with it was the long history of successful agriculture and overcoming diseases. This was followed by military conquests and unstoppable imperial glut for precious metals. This gave rise to maritime trade, new institutions, industrial revolution, and capitalism. These institutions continue to be the cornerstone of success of capitalism in the European west.

\section{North America}

North America prior to European colonization was land abundant and labour scarce. The disease environment in North America was conducive to European settlement. Mercantilist policies, fertile land, and the pursuit of religious freedom were the main drivers of European

\footnotetext{
${ }^{8}$ Note that these goods were also sold to the other parts of the empire.
} 
settlement in this part of the world. The first English settlers arrived in 1607 and established Jamestown colony in Virginia. Subsequently they also claimed Canada.

These colonies attracted settlers who came armed with Western Knowledge and Western institutions. They were also blessed with extremely fertile temperate soil. Productive agriculture, western technology and institutions, and Atlantic trade helped North America to leapfrog to an advanced capitalist economy of the next two centuries since the first settlement in Jamestown.

\section{Why Africa, Latin America and Russia fell Behind?}

\section{Africa}

Agriculture in Africa began almost 7000 years after agriculture in Europe. Therefore, the history of agriculture in Africa is fairly recent. African soil is also not as fertile as the glaciated soil of Europe. As a result the continent became trapped in the cobwebs of unfavorable geography. Furthermore, tropical diseases such as malaria and yellow fever also created almost insurmountable challenges for development in the African continent. Bhattacharyya (2009c) and Bhattacharyya (2011) presents evidence and describes the challenges faced Africa over the long run.

To summarize the African development story is a poverty trap due to almost insurmountable constraints imposed by geography and diseases. These constraints did not allow accumulation of food surplus and population growth which are essential for the development of a complex society, institutions and economy. After European contact, Africa's engagement with slave trade further distorted institutional incentives and reinforced the poverty trap (Inikori, 1977, 1992, 2000). Many of these institutions and diseases still persist and continue to exert negative impact on economic development in Africa.

\section{South America}


South America was also a settler colony after European conquest. However, the nonEuropean population density in the South was relatively higher than the North. Furthermore, it was also well endowed with mineral resources and commercial crops which are suitable for plantations. Therefore, the initial endowments of resources were quite different between North America and Central and South America.

The colonizers in South America also came from Europe in pursuit of fertile land, mercantilism, and religious freedom. However, the initial endowment dictated the type of institutions that were set up in these colonies. Colonizers after overpowering the Mayas and the Incas took control of the mines. They also set up plantations in the tropical climates. These mines and plantations were run with slave labour from Africa as there was a labour scarcity. Many of the native population perished from alien European diseases such as small pox. This type of colonization led to high inequality and perverse institutions. Institutions that was extractive and exploitative. These institutions persisted over time and continue to exert negative influence on the economic performance in Latin America.

\section{Russia}

Russia fell behind Western Europe not due to geography. Russia especially modern day Ukraine, is endowed with extremely fertile glaciated soil. Agricultural output in this part was at least as good as Western Europe. However, there were institutional weaknesses which imposed constraints and did not allow the economy to prosper at her full potential.

Landed elites in Russia had enormous power and influence over the royal court in Tsarist Russia. They were vigorously opposed to democratic pressure from the merchants and the masses. Their opposition was based on the fear that any form of democratization might lead to a loss of their exclusive control over land. Land was the main asset from which the Russian elite made their wealth. 
This opposition to democratic pressure created a highly unequal society which had implications for both political and economic institutions. A skewed distribution of economic and political power created institutions which were not conducive to capitalist development. Bitter power struggle within the society led to sharp polarization and armed revolutions. The creation of the Soviet Union and a socialist economy also altered incentives. The soviets attempted to replace economic incentives with social incentives. It worked for a while however it harmed economic incentives to innovate over the long run. As a result the soviet economy struggled from the 1970 s onwards. The legacy of these institutions continues to exert negative influence on economics in Russia.

\section{Concluding Remarks}

In this chapter I study the long term origins of poverty in developing countries. I start with an analysis of causality and the existing theories of causality used in previous studies. This section also presents the perspective on causality used in the chapter. This is followed by a unified framework relating factors such as geography, disease, colonial history, and technology in explaining the process of development in Western Europe and the New World colonies. The final section applies this framework to explain why Africa, Latin America, and Russia fell behind.

The overwhelming evidence from research on the root causes of development and poverty suggest that the explanation comprises of not a single factor but a combination of multiple factors. This is not surprising given that the process of economic development is complex and very closely related to the evolution of our species. The latest research indicates that perhaps we should spend more time and scientific energy on integrating these different factors. These factors have played out in different ways in different parts of the world. Therefore, economic history is not independent of geography, society, politics and the order at which these factors were played out. 


\section{References}

Acemoglu, D., S. Johnson, and J. Robinson. (2001). "The colonial origins of comparative development: an empirical investigation," American Economic Review, 91(5), 13691401.

Acemoglu, D., S. Johnson, and J. Robinson. (2002). "Reversal of Fortune: Geography and Institutions in the Making of the Modern World Income Distribution," Quarterly Journal of Economics, 117, 1231-1294.

Acemoglu, D., S. Johnson, and J. Robinson. (2005). "The Rise of Europe: Atlantic Trade, Institutional Change and Economic Growth," American Economic Review, 95(3), 546-579.

Acemoglu, D., and S. Johnson. (2005). "Unbundling Institutions," Journal of Political Economy, 113(5), 949-995.

Allen, R. (2008). “A Review of Gregory Clark's A Farewell to Alms: A Brief Economic History of the World," Journal of Economic Literature, 46(4), 946-973.

Amsden, A. (2001). "The Rise of "The Rest": Challenges to the West from LateIndustrializing Economies," New York: Oxford University Press.

Arrighi, G., T. Hopkins, and I. Wallerstein. (1989). “Anti-systemic Movements,” London: Verso.

Bhattacharyya, S. (2009a). "Institutions, Diseases and Economic Progress: A Unified Framework," Journal of Institutional Economics, 5(1), 65-87.

Bhattacharyya, S. (2009b). "Unbundled Institutions, Human Capital, and Growth," Journal of Comparative Economics, 37, 106-120.

Bhattacharyya, S. (2009c). "Root Causes of African Underdevelopment," Journal of African Economies, 18(5), 745-780. 
Bhattacharyya, S. (2011). "Growth Miracles and Growth Debacles: Exploring Root Causes," Cheltenham: Edward Elgar.

Bloom, D., and J. Sachs. (1998). "Geography, Demography, and Economic Growth in Africa," Brookings Papers on Economic Activity, 2, 207-295.

Clark, G. (2007). “A Farewell to Alms: A Brief Economic History of the World," Princeton and Oxford: Princeton University Press.

Collier, P. and J.W. Gunning. (1999). "Explaining African Economic Performance,” Journal of Economic Literature, 37(1), 64-111.

Diamond, J. (1997). "Guns, Germs and Steel: The Fate of Human Societies," W.W. Norton \& Co., New York.

Diamond, J. (2012). “What Makes Countries Rich or Poor?” New York Review of Books, June $12,70-75$.

Engerman, S., and K. Sokoloff. (2001). "Inequality, Institutions, and Differential Paths of Growth Among New World Economies," Working Paper, University of California, Los Angeles.

Evans, P. (1995). “Embedded Autonomy: States and Industrial Transformation,” Princeton NJ: Princeton University Press.

Findlay, R., 1990. "The Triangular Trade" And The Atlantic Economy Of The Eighteenth Centrury: A Simple General-Equilibrium Model," Princeton Studies in International Economics 177, International Economics Section, Department of Economics Princeton University.

Gallup, J., and J. Sachs. (2000). “Agriculture, Climate, and Technology: Why are the Tropics Falling Behind?” American Journal of Agriculture Economics, 82, 731-737.

Gallup, J., and J. Sachs. (2001). “The Economic Burden of Malaria,” American Journal of Tropical Medicine and Hygiene, 64(1-2), 85-96. 
Gallup, J., J. Sachs, and A. Mellinger. (1998). "Geography and Economic Development," NBER Working Paper No.w6849, December.

Galor, O. and O. Moav. (2006). "Das Human-Kapital: A Theory of the Demise of the Class Structure," Review of Economic Studies, 73, 85-117.

Glaeser, E., R. LaPorta, F. Lopez-de-Silanes, and A. Shleifer. (2004). "Do Institutions Cause Growth?" Journal of Economic Growth, 9, 271-303.

Hall, R., and C. Jones. (1999). "Why do some countries produce so much more output per worker than others?" Quarterly Journal of Economics, 114(1), 83-116.

IFAD (2011). Rural Poverty Report: New Realities, New Challenges, New Opportunities for Tomorrow's Generation, United Nations, Rome: December.

Inikori, J. (1977). “The Import of Firearms into West Africa, 1750-1807: A Quantitative Analysis," Journal of African History, 18, 339-368.

Inikori, J. (1992). “The Chaining of a Continent: Export Demand for Captives and the History of Africa South of the Sahara, 1450-1870," Institute of Social and Economic Research, University of the West Indies, Mona, Jamaica.

Inikori, J. (2000). "Africa and the Trans-Atlantic Slave Trade," In T. Falola (eds.), Africa Volume 1: African History before 1885, 389-412, Durham, North Carolina: Carolina Academic Press.

Kiszewski, A., A. Mellinger, A. Spielman, P. Malaney, S. Sachs, and J. Sachs. (2004). “A Global Index Representing the Stability of Malaria Transmission,” American Journal of Tropical Medicine and Hygiene, 70(5), pp. 486-498.

Knack, S., and P. Keefer. (1995). "Institutions and Economic Performance: Cross-country Tests using Alternative Institutional Measures," Economics and Politics, 7(3), 207227. 
Landes, D. (1998). "The Wealth and Poverty of Nations: Why Some Are So Rich and Some So Poor," London: Abacus.

Lange, M., J. Mahoney, M. vom Hau. (2006). "Colonialism and Development: A Comparative Analysis of Spanish and British Colonies," American Journal of Sociology, 111(5), 1412-1462.

LaPorta, R., F. Lopez-de-Silanes, A. Shleifer, and R. Vishny. (1999). "The Quality of Government," Journal of Law, Economics and Organization, V15, N1, 222-279.

Lipset, S. (1959), 'Some Social Requisites of Democracy: Economic Development and Political Legitimacy', American Political Science Review, 53: 69-105.

Manning, P. (1981). “The Enslavement of Africans: A Demographic Model," Canadian Journal of African Studies, 15(3), 499-526.

Manning, P. (1982). "Slavery, Colonialism and economic Growth in Dahomey, 1640-1960," Cambridge: Cambridge University Press.

Milanovic, B. (2005). "World Apart: Measuring International and Global Inequality," Princeton NJ: Princeton University Press.

Miller, J. (1988). "Way of Death: Merchant Capitalism and the Angolan Slave Trade, 17301830," University of Wisconsin Press, Madison.

Mokyr, J. (1990). "The Lever of Riches: Technological Creativity and Economic Change," New York: Oxford University Press.

Montesquieu, C. (1748 [1989]). "The Spirit of Laws," New York, Cambridge University Press.

Moore, B. (1966). "Injustice: The Social Bases of Obedience and Revolt," White Plains: New York.

North, D. (1989). “Institutions and Economic Growth: An Historical Introduction,” World Development, 17(9), 1319-1332. 
North, D. (1994). "Economic Performance Through Time," American Economic Review, 84(3), 359-368.

Nunn, N. (2008). “The Long-Term Effects of Africa's Slave Trades," Quarterly Journal of Economics, 123(1), 139-176.

Olsson, O., and D. Hibbs. (2000). "Biogeography and Long-Run Economic Development," Working Paper in Economics No. 26, Göteborg University.

Parker, P. (2000). “ Physioeconomics: The Basis for Long-Run Economic Growth,” The MIT Press, Cambridge, Massachusetts.

Rodrik, D., A. Subramanian, and F. Trebbi. (2004). "Institutions Rule: the Primacy of Institutions over Geography and Integration in Economic Development," Journal of Economic Growth, 9, 131-165.

Sachs, J. (2003). “Institutions Don't Rule: Direct Effects of Geography on Per Capita Income," NBER Working Paper No.w9490, February.

Sachs, J., and A. Warner. (1995). "Natural Resource Abundance and Economic Growth," NBER Working Paper No.w5398, December.

Sachs, J. and A. Warner. (1997). "Sources of Slow Growth in African Economies," Journal of African Economies, 6(3), 335-376.

Schumpeter, J. (1934). “The Theory of Economic Development,” Cambridge, Mass.: Harvard University Press.

Smith, A. (1776 [1976]). "The Wealth of Nations," Cannan ed. Chicago: University of Chicago Press.

Tawney, R. (1926). "Religion and the Rise of Capitalism,” John Murray: London.

Thelen, K. (1999), 'Historical Institutionalism in Comparative Politics', American Review of Political Science, 2: 369-404. 
Thelen, K. (2000), 'Timing and Temporality in the Analysis of Institutional Evolution and Change', Studies in American Political Development, 14: 101-108.

Weber, M. (1930). "The Protestant Ethic and the Spirit of Capitalism," Allen and Unwin: London.

Zohary, D., and M. Hopf (2000). "Domestication of Plants in the Old World," New York: Oxford University Press.

Figure 1: Evolution of per capita income across nations, $1950-2005$

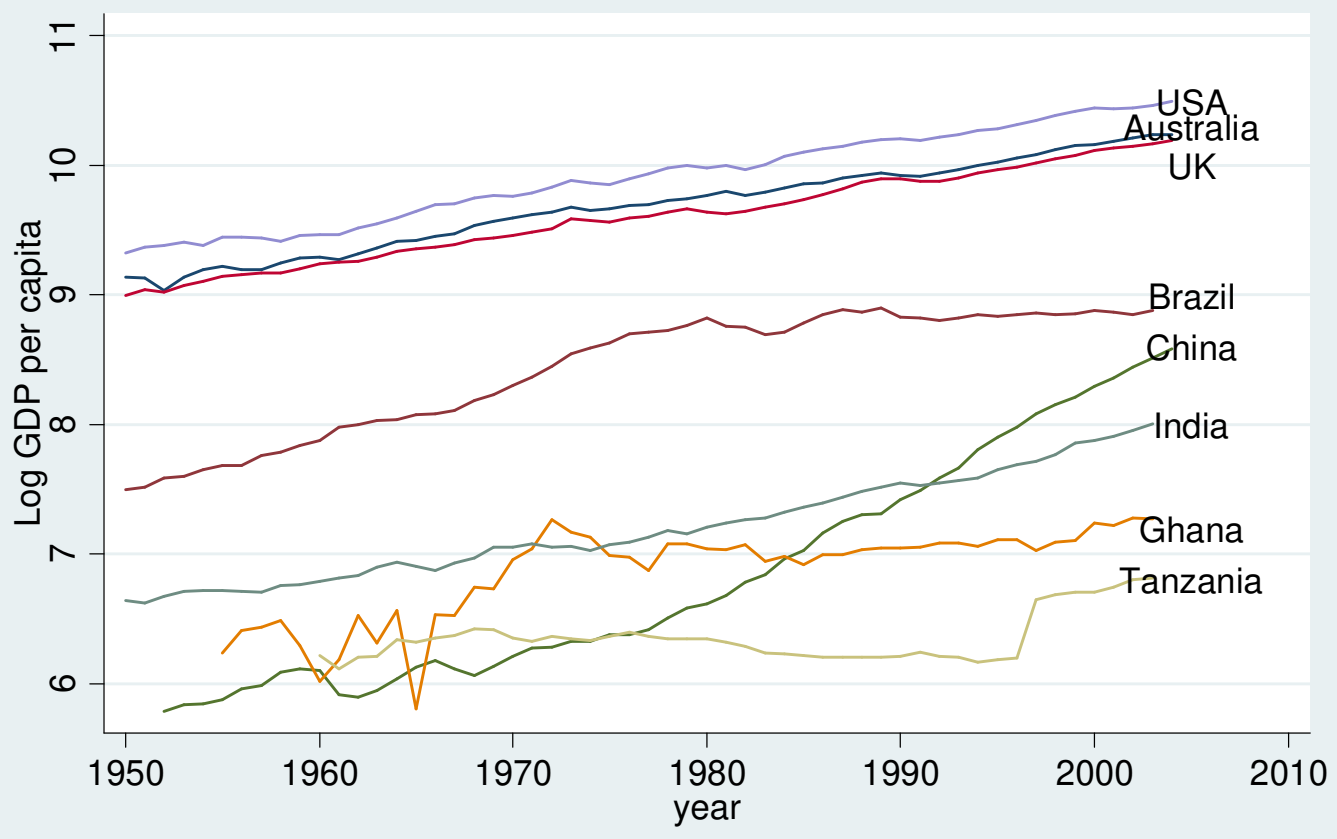


Table 1: History and Poverty around the Globe

\begin{tabular}{|c|c|c|c|c|}
\hline Western Europe & North America & South America & Africa & Russia \\
\hline $\begin{array}{c}\text { Glaciated Fertile Soil } \\
\downarrow \\
\text { Food Surplus } \\
\downarrow \\
\text { Population Growth } \\
\downarrow \\
\text { Conflict, } \\
\text { technological } \\
\text { progress, and stronger } \\
\text { institutions } \\
\downarrow \\
\text { Conflict induced need } \\
\text { for more government } \\
\text { revenue } \\
\downarrow \\
\text { Exploration of the } \\
\text { Atlantic route and } \\
\text { hunt for precious } \\
\text { metals } \\
\downarrow \\
\text { Plunder and import of } \\
\text { precious metals lead } \\
\text { to inflation } \\
\downarrow \\
\text { Mercantilist policy to } \\
\text { stop outflow of } \\
\text { precious metals and } \\
\text { rising inflation } \\
\downarrow \\
\text { Atlantic trade in } \\
\text { manufacturing } \\
\downarrow \\
\text { Induces institutional } \\
\text { change and rise of } \\
\text { capitalist institutions } \\
\downarrow \\
\text { More inclusive } \\
\text { political institutions } \\
\text { which sustains the } \\
\text { progress of capitalist } \\
\text { development } \\
\downarrow \\
\text { along with inclusive } \\
\text { political institutions } \\
\text { lead to shared } \\
\text { prosperity }\end{array}$ & $\begin{array}{c}\text { Glaciated Fertile Soil } \\
\text { but land abundant and } \\
\text { labour scarce society } \\
\downarrow \\
\text { European migration } \\
\text { and settlement } \\
\downarrow \\
\text { Migration of } \\
\text { European technology } \\
\text { and institutions } \\
\downarrow \\
\text { Land abundance and } \\
\text { smaller family farms } \\
\text { to cultivate crops such } \\
\text { as wheat and corn } \\
\text { leads to more } \\
\text { egalitarian initial } \\
\text { income distribution } \\
\downarrow \\
\text { More egalitarian } \\
\text { distribution of } \\
\text { political power } \\
\downarrow \\
\text { More inclusive and } \\
\text { democratic political } \\
\text { institutions } \\
\downarrow \\
\text { Atlantic trade with } \\
\text { Europe and the rest of } \\
\text { the world } \\
\downarrow \\
\text { Successful capitalism } \\
\text { and shared prosperity }\end{array}$ & $\begin{array}{c}\text { Land abundant and } \\
\text { labour scarce society } \\
\downarrow \\
\text { Spanish and } \\
\text { Portuguese conquest, } \\
\text { European migration } \\
\text { and settlement } \\
\downarrow \\
\text { Geographical } \\
\text { endowment } \\
\text { conducive for mining } \\
\text { of precious metals and } \\
\text { plantation } \\
\downarrow \\
\text { Small group of } \\
\text { colonial owners of } \\
\text { plantations and mines } \\
\text { run with large number } \\
\text { of native American } \\
\text { labour or African } \\
\text { slave labour } \\
\downarrow \\
\text { Skewed distribution } \\
\text { of economic and } \\
\text { political power } \\
\downarrow \\
\text { Exploitative and } \\
\text { autocratic political } \\
\text { institutions } \\
\downarrow \\
\text { Expropriation of } \\
\text { private property with } \\
\text { weak property rights } \\
\text { and contracting } \\
\text { institutions } \\
\downarrow \\
\text { Atlantic trade in } \\
\text { primary products and } \\
\text { metals with Europe } \\
\text { and the rest of the } \\
\text { world } \\
\downarrow \\
\text { Unsuccessful } \\
\text { capitalism and decline } \\
\text { due to institutional } \\
\text { failure }\end{array}$ & $\begin{array}{c}\text { Infertile soil, low } \\
\text { agricultural } \\
\text { productivity, and high } \\
\text { disease incidence } \\
\downarrow \\
\text { Land abundant and } \\
\text { labour scarce society } \\
\downarrow \\
\text { Disease and low } \\
\text { agricultural } \\
\text { productivity continues } \\
\text { to be a major } \\
\text { constraint to } \\
\text { development } \\
\downarrow \\
\text { European contact, } \\
\text { plunder, and colonial } \\
\text { institutions } \\
\downarrow \\
\text { Exploitative and } \\
\text { autocratic political } \\
\text { institutions } \\
\downarrow \\
\text { Weak property rights } \\
\text { and contracting } \\
\text { institutions } \\
\downarrow \\
\text { Atlantic slave trade } \\
\text { weakens sex ratio and } \\
\text { institutions } \\
\downarrow \\
\text { Poverty trap due to } \\
\text { geography, disease, } \\
\text { and institutional } \\
\text { failure }\end{array}$ & 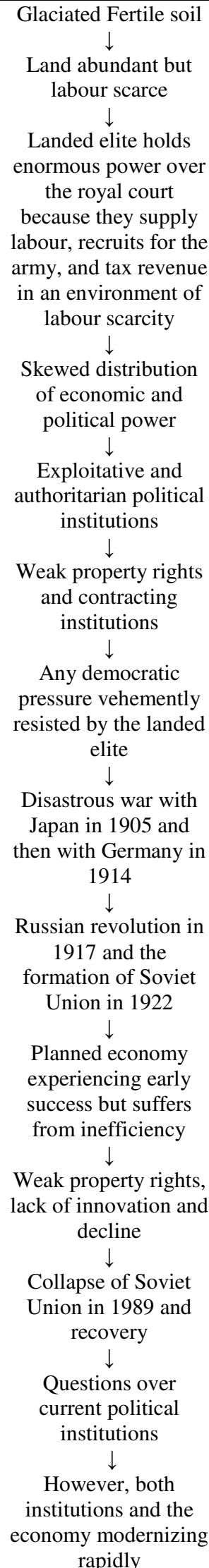 \\
\hline
\end{tabular}

